E, acima de tudo, deve existir um ideal, uma crença, uma mística comum: a de que tudo isso se inspire na dignidade e na elevação đa pessoa humana - princípio sem o qual todos os ideais se destroem por si mesmcs. É o princípio da justiça social que deve inspirar essa mística. E, a par disso, devem-se recolocar os valôres nos seus lugares próprios, valorizando-se as pessoas e as coisas pelo seu conteúdo humano e espiritual e não apenas pelo interêsse ou vantagens que representam.

Nem no interêsse, nem muito menos no ódio, se devem inspirar as aspirações da justica e da harmonia sociais; mas, sim, na solidariedade humana, na compreensão humana, no ancor humano. Este é o princípio que deve inspirar as categorias de produção, na busca do desenvolvimento nacional e da justiça social. Tôdas as normas ae Direito tornam-se ineficazes se não forem valorizadas por êsse sôpro de amor e de solidariedade entre os homens.

Para finalizar, ainda numa homenagem ao eminente professor Eloy José da Rocha - de quem haurimos os ensinamentos aqui expostos - repetimos neste momento as palavras com que aquêle ilustre mestre concluía a exposição desta matéria, em sua cátedra na Faculdade de Direito:

"Se fôsse possível reunir num prato de balança as leis mais perfeitas do mundo, e no outro se colocasse uma rosa, a balança deveria pender para o lado da rosa, por causa do belo, por causa da vida, já que a rosa é a flor que mais expressão de vida tem.

E o homem, a vida, isso é que deve ser valorizado."

\section{PROBLEMÁTICA FILOSÓFICO-JURÍDICA ATUAL}

PROF. JACY DE SOUZA MENDONÇA

\section{A problemática geral da Filosofia do Direito}

No convívio humano, o Direito é um dado. Vive o homem, necessàriamente, segundo regras imanentes ao próprio convívio. Não as recebe, porém, apoditicamente, como algo indiscutível a que deve apenas submissão; problematiza o conteúdo da regra, a fim de verificar-se, e até que ponto, deve a ela realmente submeter-se. $\mathrm{Pa}$ ra isso, carece de compreendê-la, compreensão que permanece no limiar de um registro empírico ou ascende ao nível do conceito universal e necessário.

Descrita, assim, a posição existencial do homem face ao Direito, registram-se simultâneamente as duas atitudes fundamentais que, como sujeito, assume face a êste objeto: apreciá-lo em seu conteú do, em seu valor intrínseco, ou representá-lo conceitualmente. Em Filosofia do Direito, qualificam-se estas duas atitudes, respectivamente, como axiológica (ou deontológica) e lógica (ou conceitual) e delas exsurgem dois problemas fundamentais, redutíveis a duas perguntas: que vale o Direito? que é o Direito?

A resposta à primeira questão (referente ao valor do Direito) oscila, teórica e històricamente, entre duas hipóteses extremas: o valor do Direito emerge da fôrça da natureza ou da natureza da fôrça. É o esquema do diálogo entre SóCRATES e TRASÍMACO, de que dá notícia PLATÃO no Livro I da República. Diálogo intemporal. Os interlocutores nos servem como símbolo das perspectivas extremas possíveis em que o homem se põe face ao conteúdo

* Livre-docente de Filosofia do Direito. 
da regra jurídica. É o registro da aporia que determina no espírito humano a exigência de investigar sôbre o valor ou desvalor do $\mathrm{Di}$ reito, a exigência de optar entre os abismos da redução do jurídico a fôrça (negando, conseqüentemente, o Direito em si) ou o eterno retôrno (1) a uma interpretação que vê a fôrça do Direito como emanação de sua própria natureza, em última análise a natureza racional, social e livre do homem.

A atitude axiológica face ao Direito, para descobrir ou negar o que nêle se contém de valioso, supõe outra posição, também fundamental, do homem face às coisas: a contemplação desinteressada, a especulação pura sôbre o Direito, que corresponde à exigência do espírito de apreender o conteúdo inteligível do objeto, conceituá-lo. O representar é contemporâneo ao valorar. Perguntar sôbre o que vale o Direito implica em perguntar sôbre o que êle é, qual a sua essência. Satisfaz-se esta necessidade mesmo quando a resposta permanece ao nível de um registro meramente empírico, revestido de um mínimo de interpretação crítica generalizadora. No plano científico ou filosófico, a pergunta requer solução que dê, do Direito, representação universal, independente de sua concreção temporal-espacial, de sua revelação na história humana através das formas várias dos ordenamentos jurídicos possíveis. Busca-se o Direito em si mesmo, independentemente de seu fenômeno histórico, embora se processe a busca através das manifestações históricas. Tarefa infinda (2), tão inexaurível como a que investiga sôbre o valor (3), porque dirigidas ambas ao mistério do ser. É o problema conceitual do Direito, a procura de uma idéia de Direito universalmente válida.

$\mathrm{Na}$ medida em que o pensador procura desvendar o mistério do jurídico, mediante a determinação de sua essência, percebe que qualquer resposta à dificuldade não só está inflưenciada por pressupostos relativos à sua concepcão sôbre o próprio conhecer humano, como também envolve tomada de posição mais profunda, referente à radicação ontológica do Direito. São os problemas gnosiológico e ontológico jurídicos, implícitos nos temas da conceituação e valoração do Direito.

Não é possível, em verdade, tentar a solução do problema conceitual do Direito sem o preliminar tratamento da questão relativa à possibilidade de o conceito, universal e necessário, adequar-se à realidade concreta, particular e contingente. $\mathrm{O}$ estudo da possibilida-

(1) - A expressão aproveita o título do trabalho de H. ROMMEN, Die ewige Wiederkehr des Naturrechts», Muenchen, 1936

(2) - «Noch suchen die Juristen eine Definition zu ihrem Begriffe von Recht» (KANT, in Kritik der reinen Vernunft)

(3) - HESSEN, J. - Wertphilosophie, IV/II. de do conhecimento do Direito, suas origens, essência, formas, e dos critérios do conhecimento verdadeiro, constituem a temática gnosiológico-jurídica, cujos resultados embasam as soluções possíveis dos problemas conceitual e axiológico do Direito.

Por outro lado, o valor do Direito, a capacidade intrínseca que tem de imperar, enquanto Direito, é algo: insere-se numa ontologia - a ontologia do dever. Há um imperioso perguntar sôbre o ser do dever ser jurídico (4). Há um problema ontológico jurídico pressuposto na solução do problema axiológico jurídico

A êstes quatro problemas acresce mais um a Filosofia do Direito: o problema fenomenológico. $\mathrm{O}$ qualificativo não é tomado a Husserl mas a Hegel. Busca examinar o Direito de um ponto de vista simultâneamente axiológico, sociológico e histórico; mais precisamente, verificar a forma como, através da história, revela-se o valor Justica no convívio. Atribui-se a DEL VECCHIO a inclusão dêste problema na temática filosófico-jurídica; inclusão que seria explicável como concessão do criticismo do professor romano à Escola Histórica do Direito, decorrente da influência por ela exercida em sua formação inicial (5). Realmente, em DEL VECCHIO, a par da indagação relativa à forma lógica (adiáfora) do Direito, interessa o estudo do conteúdo histórico e ideal (6). Três temas incomunicáveis. O primeiro, correspondente ao exame das cond:cões subjetivas, formais, de pensar, de relacionar a experiência jurídica como as categorias do entendimento em KANT; os dois outros, relativos ao conteúdo a ser modelado por esta forma: conteúdo axiológico, ideal, de um lado (que preocupa o autor especialmente em "La Giustizia") e conteúdo experimental (sociológico, histórico, etnológico ou psicológico), que o preocupou em inúmeros outros trabalhos publicados (7).

(4) - MENDONCA, J. - Fundamentos do Imperativo Jurídico P.A., $1963 .-$ Ser e Dever Ser Jurídico (in Rev. Jurisprudência do T.J. do RGS, 1967, ano II, Nr. 6)

(5) - RECASENS SICHES - Panorama del Pensamiento Jurídico en el Siglo XX, México, 1963, I/80-81.

(6) - «Non dissi certamente cosa nuova quando, in un'opera giovanile, sosteni la necessità di distinguere la forma dal contenuto del diritto: intendo per forma nel senso della più alta tradizione filosofica, la sostanza o l'essenza, e non già l'apparenza superficiale. (...) Nulla fu mai più lontano dal mio pensiero, nel sostenere quella distinzione, che limi. tare il campo della Filosofia giuridica alla sola indagine della forma logica; chè anzi affermai la pari importanza dello studio del contenuto, storico e ideale» (DEL VECCHIO, La Filosofia del diritto e i suoi problemi, RIFD, 1958, p. 9)

(7) - DEL VECCHIO - Presupposti, Concetto e Principio del Di- 
O problema fenomenológico, porém, é indiscutível exigência de todo sistema filosófico-jurídico que não ignore a realidade concreta do Direito, experimentável no convivio. O exame realista do Direito deve, necessàriamente, partir do material depositado através da história, revelador da forma como os homens conceberam e viveram o valor Justiça.

Não visa o presente estudo ao tratamento da problemática geral da Filosofia do Direito; quer, isso sim, descrever as linhas fundamentais do pensamento filosófico-jurídico atual, relativamente ao Direito. Pretende verificar como, nos nossos dias, se pensa e se vive o Direito.

\section{A ruptura entre "Sein" $e$ "Sollen" na idade Moderna}

Tomando-se DESCARTES como ponto de partida, chega-se a KANT como o pensador ern quem foram traçadas as grandes linhas que presidem à Filosofia dos nossos dias. $\mathrm{E}$ embora não caiba aqui a análise do pensamento de KANT, é necessário registrar algumas de suas conclusões mais significativas para o estudo do Direito. Entre estas, a ruptura entre ser e pensar (entre a idéia e a realidade a que corresponde): "das Ding an sich" é inacessível ao pensamento humano, que permanece prisioneiro de suas próprias formas subjetivas (com o que se constitui o fenômeno) incapaz de verificar a correspondência dêste condicionamento ao mundo do objeto (ó nôumeno). Essência e existência são, destarte, incomunicáveis. Não menos importante a ruptura entre ser e dever se: o ser é inacessível ao pensar mas o dever ser, porque independe do ser, segundo KANT, impõe-se ao querer humano e pode ser objeto de crítica especial, a partir de determinados postulados.

Este corte radical da Filosofia de Kant apresenta-se ainda hoie nos trabalhos de Filosofia do Direito. É nítida a dualidade de orientação dos filósofos do Direito: ou, aderindo à posição básica de KANT, tratam o Direito como mero dever ser, sem a mínima relação com o ser - e disso Hans KELSEN é ainda a melhor ilustração (8); ou, nas tentativas de superação da estrutura kantiana, procuram encontrar uma forma de fazer com que o dever-ser-jurídico não paire no irreal mas se afirme ontològicamente ao pensamento.

(8) - «Do fato de que uma coisa é não se pode deduzir que alguma coisa deve (soll) ser, assim como do fato de que uma coisa deve (soll) ser não se pode deduzir que alguma coisa é. O fundamento da validade de uma norma não pode ser senão a validade de uma outra norma» (KELSEN, Teoria Pura do Direito, $2^{\text {a }}$ ed., tr. italiana, p. 217)

\section{A Fenomenologia Jurídica}

$\mathrm{O}$ mais vigoroso brado de alerta sôbre a necessidade de retornar à realidade do objeto, perdida em KANT, dá-nos HUS SERL: "Zurueck zu den Sachen selbst!" - E uma nova Ontologia se propõe, com a pretensão de ser não abstrata, como a aristotélica, mas concreta; não uma ciência do ser mas uma ciência dos sêres (das coisas).

O ponto de partida da preocupação de HUSSERL encontrase, pois, na questão da origem das idéias, onde duas hipóteses explicativas se propunham: tomá-las como resultantes de uma abs. tração, tendo a experiência do individual concreto por base e uma operação racional por acabamento como faziam ARISTóTELES e todos os seus seguidores; ou tomá-las como diretamente encontráveis num mundo próprio, um mundo platônico, acessíveis a uma intuição essencial pré-terrena e a uma reminiscência. - A razão última da dificuldade proposta pela Fenomenolcgia é, pois, ainda, a dramática antinomia entre o mundo das coisas (individuais, concretas, contingentes) e o mundo das idéias (universais, abstratas, necessárias); a vocação de HUSSERL está em tentar forma tal de relacionar êstes dois mundos que lhe permita compreender e afirmar a correspondência entre pensar e ser, superando a ruptura kantiana.

Com êste propósito, recusa, de início, o mundo platônico das idéias, uma vez que êste pressupõe a ruptura com o mundo das coisas (9) e reduz o conhecer à reminiscência (10), ao diálogo da alma consigo mesma (11). Recusa também a explicação das idéias como extração (abstração) das ccisas, como no aristotelismo, pretendendo que a descoberta da idéia se dá nas coisas, segundo peculiar forma de vê-las, de intuílas - é a experiência das idéias nos fenômenos (que não são algo que contraste com o ser, mas sim o próprio ser). O Ego, intencionalmente voltado aos objetos individuais, põe entre parêntesis, desconecta, por assim di-

(9) - «(A idéia) é, por si, para si, consigo, sempre imutável; e as outras coisas... participam dela de tal forma que, enquanto estas nascem e perecem, ela (a idéia) nem cresce, nem diminui, nem sofre qualquer outra mudança» (PLATÃO - Banquete - XXIX, $211 \mathrm{~b}$ ).

(10) - «A alma, sendo imortal e tendo renascido muitas vêzzes e visto as coisas lá de cima e as daqui de baixo, tudo, em suma, tudo aprendeu... aprender é verdadeiramente sempre uma reminiscência» (PLA TÃO - Menon - XIV/XV, 81-82)

(11) - «O ato de pensar parece-me que, efetivamente, não é senão um diálogo que a alma tem consigo mesma, interrogando e respondendo, afirmando e negando». (PLATÃO - Teetetos - XXXII, 190). 
zer (12), o acessório, o secundário, o tradicional que a êle se oferta e, neste processo, capta, simultâneamente, o Eidos, a essência ideal do objeto, uma essência pura (13). A gênese das idéias não se dá num esquema de anterioridade-ulterioridade, ou num esquema de mediação, relativamente ao fenômeno, mas no plano da simultaneidade, da concomitância.

Não só. A própria experiência fenomenal é dispensável, podendo o espírito apreender as idéias diretamente, originàriamente, através da variação imaginária (Wesensschau), um esfôrço de pensar que conquista a essência ideal na medida mesma em que produz as notas que constituem o Eidos; composição limitada apenas pela inverdade; composição que, relativamente à apreensão da idéia, equivaleria à percepção sensível na apreensão das coisas (14).

É bem verdade que, em última análise, afirma a fenomenologia um outro mundo (à Platão, mesmo), o mundo das essências ideais, nova região de ser (15), em paralelo ao mundo dos objetos singulares; naquele, e não neste, situam-se as idéias. Resta sempre, por isso, a necessidade de explicar a forma de relacionamento real e gnosiológico dêstes dois planos, angústia que não se afastou das cogitações de HUSSERL, o qual, na "Crise da Ciência Européia", fala numa experiência vital (Lebenswelt), uma intuição de totalidade, "a priori", como forma de apreensão do Eidos, superior e anterior à Wesensschau: como que a experiência do ser, da totalidade, condicionante e possibilitadora da experiência dos sêres, da particularidade, em forma universal.

A tentativa de HUSSERL no sentido de recuperar o abismo kantiano repercute imediatamente no pensamento jurídico. Em 1913, enquanto eram publicados os primeiros trabalhos de Husserl, o jurista alemão Adolf REINACH publicava também sua forma de

(12) — «Pôr, por assim dizer, 'fora do jôgo', desconectar, colocar entre parêntesis'» (HUSSERL - Idéias, p. 71)

(13) _- «... a essência (Eidos) é um objeto de nova índole. Assim como o dado na intuição individual ou empírica é um objeto individual, o dado na intuição essencial é uma essência pura» (HUSSERL, Idéias, pág. 21).

(14) - _... podemos apreender uma essência em si mesma, originàriamente, a partir das correspondentes intuições empíricas e, igual mente, intuições não experimentativas, não apreensivas de algo existen te, antes meramente imaginativas» (HUSSERL - Idéias, pág. 23). $\ll \ldots$ a intuição de essências é um ato em que estas se dão originàriamente e enquanto tal, um ato análogo à percepção sensível e não à imagi nação» (idem, pág. 58).

(15) - «Que pode, com efeito restar quando se desconectou o mundo inteiro, inclusive nós mesmos com nôvo cogitare?... uma nova região de ser (puro)» (HUSSERL - Idéias, pág. 75) ver o Direito em perspectiva fenomenológica (16). Morto aos 34 anos de idade, na primeira grande guerra, dêle nos resta, além do trabalho acima referido, apenas uma conferência sôbre o mesmo tema (17).

Sustenta REINACH que o conhecimento jurídico se processa exatamente como se propõe na gnosiologia husserliana: o pensamento está intencionalmente voltado às vivências determinadas do mundo jurídico (são as experiências do Direito Positivo ou as situações jurídicas concretas); pondo entre parêntesis, desconectando esta realidade empírica do Direito, capta a inteligência o Eidos jurídico, os conceitos jurídicos, que são estruturas ontológicas imanentes e "a priori", condicionantes da experiência particular. A plica, então, o método proposto a institutos jurídicos como a promessa, a prcpriedade e a representação; é êste o esquema de sua obra, cujo manifesto objetivo é revelar como a captação da essência ideal de um instituto jurídico envolve a descoberta das regras que essencialmente o integram e é, destarte, o autêntico processo legislativo positivo (processo maiêutico, similar ao de Sócrates no diálogo com o escravo de Manon). Apreendida a idéia correspondente a um instituto jurídico, apreende-se simultâneamente sua legislação natural, da qual a legislação positiva será apenas explicitação lógica.

Sirva sòmente REINACH como ilustração da corrente fenomenológica. Não só por ser cronològicamente o primeiro mas também pelo valor intrínseco de sua obra. Seria mesmo impossível, em rápido planejamento, traçar o perfil de concepcões como as de Helmuth GOING, Erich FECHNER, Félix KAUFMANN, Fritz SCHREIER, Carlos COSSIO, Paul AMSELEK, Nicos POULAN'T. ZAS, J. L. GARDIES, etc.

$\mathrm{O}$ mérito da concepção fenomenológica do Direito consiste, em suma, no registro da necessidade de ultrapassar o dado concreto do Direito Positivo, como condição de sua própria inteligibilidade; na afirmação da possibilidade de captação da essência do jurídico; na revelação da regra positiva como derivada de uma legislação natural.

A fenomenologia se revela, porém, tentativa frustrada de solucão do conflito kantiano. $\mathrm{O}$ retôrno às coisas em si mesmas, que lhe dá linha programática, tem por epílogo o encontro de um Eidos inconfundivel com elas: mais que distinto da realidade, o Eidos

(16) - Adolf REINACH - «Die apriorischen Grundlagen des buer(16) - Adolf REINACH - «Die apriorischen Grundlagen des buergerlichen Rechts» (in

(17) - Adolf REINACH - «Was ist Phäenomenologie?», conferên cia pronunciada em Marburg em 1914, publicada em 1921. 
apresenta discutivel relacionamento com ela. REINACH (para manter a crítica apenas em perspectiva jurídica) vai a ponto de sustentar a possibilidade de dissintonia entre o Eidos e a realidade jurídica; dito em outras palavras, entre a essência eidética apriórica do Direito e as regras e instituições jurídicas; ou ainda, entre a norma-jurídica-fato e a norma-jurídica-essência. E como inexiste no sistema possibilidade de hierarquizar êstes planos, já que ao Eidos não corresponde qualquer conotação axiológica, torna-se imprati. cável relacioná-los. "O Direito Positivo, diz REINACH, pode realizar estas leis 'a priori' em seus preceitos, mas pode também contrariá-las; pois bem, ainda quando a elas se opõe, não fere, em absoluto, sua essência". O que se estabelece, portanto, é um jusnaturalismo idealista, uma dualidade de ordens jurídicas incomunicáveis (a ordem jurídica natural ideal e a ordem jurídica positiva). Por estas razôes, a crítica não tem poupado tal forma de ver o $\mathrm{Di}$ reito. Dela diz, por exemplo, RECANSENS SICHES que se trata da "solução de um problema que não existe", pois "não estuda nem o Direito que é, nem o que deve ser" (18); ou, como sublinha Nicos POULANTZAS, a apreensão da norma jurídica natural no Eidos, para ulterior tradução lógica em plano positivo, não passa de processo tautológico pois, em verdade, atribui-se prèviamente ao conceito aquilo que dêle, a seguir, se pretende extrair" (19).

Desta forma, o rumo proposto por HUSSERL e acolhido pelos fenomenólogos da ciência jurídica conduz, ou reconduz, às essências platônicas e não ao real. Permanecem íntegros e incomunicáveis os dualismos clássicos: ser-pensar, idéia-realidade, essência-existência, númeno-fenômeno.

\section{O existencialismo jurídica}

A época em que vivemos registra outra orientação de pensamento voltada à superação do dualismo - o existencialismo.

Êste propósito é explícito na obra de SARTRE, que sugere co. mo forma de solução do conflito a extinção de um dos polos do bi. nário. "O pensamento moderno, diz, êle, realizou considerável progresso reduzindo o existente à série de fenômenos que o revelam." - "O ser de um existente é exatamente seu parecer." "Nossa teoria do fenômeno substituiu a realidade da coisa pela objetividade do fenômeno." (20)

(18) - RECASENS SICHES - Panorama del Pensamiento Juridico en el Siglo XX, I/262-3

(19) - N. POULANTZAS - Notes sur la phénoménologie et l'existentialisme juridiques (in $A B D, 196$

(20) - SARTRE - L'être et le néant - Introdução.
Preocupação básica é ainda o retôrno à coisa concreta. Busca-se, porém, o homem concreto. $\mathrm{E}$ o foco central da preocupação é aquilo que têm por mais concreto no homem - sua existên. cia. Institui-se, por isso, uma antropologia, ou uma ontologia da existência humana, na qual só há lugar para o tratamento da essência do homem como e enquanto derivada d aprópria existência

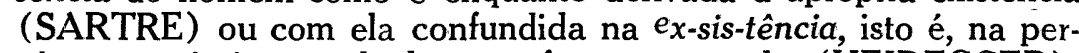
pétua exteriorização do homem face ao mundo (HEIDEGGER).

Em que pese a ambigüidade do têrmo, pode-se encontrar como linha fundamental do pensamento existencialista a preocupação pelo homem como existência concreta, em plano de atitude. O homem-fenômeno aparece, então, como um ser derelicto, abandonado na existência. Lançado num mundo que não criou e que não pode pôr entre parênteses, do qual não pode libertar-se. "Condenado a ser livre" (21). - O nada é o ponto de partida do existir e o têrmo final da historicidade. À medida em que se faz, no existir, o homem se distancia de si mesmo, perde-se, niilifica-se. A existência é, portanto, um processo dialético no qual o homem ao mesmo tempo constrói sua essência no fazer-se e tende para o nada, para a perda de seu próprio ser. É o fazer-se do nada e $c$ niilificar-se do ser. E entre êstes dois nadas situa-se a temporalidade, dimensão fundamental do homem. Êle não está feito para o eterno, como dizia SPINOZA - "nós ncs sentimos e nos experimentamos como eternos" (22) — mas para o tempo, para a morte. Por isso, é apenas abertura para a auto-construção, busca de realização da própria essência através do representar e do fazer ("fazer e, fazendo, fazer-se") — é pro-jeto. Está voltado apenas para o futuro: não é, mas tende a ser - e nisto está a sua transcendência. - $-E$ uma existência face ao mundo. $E$ na medida em que, pela liberdade, intende ao mundo, cria os valôres. $\mathrm{O}$ bem e o justo são, assim, o mero resultado de uma escolha. "Escolher ser isto ou aquilo é afirmar, ao mesmo tempo, o valor do que escolhemos, nois, nós não podemos escolher o mal; aquilo que escolhemos é sempre bom e nada pode ser bom para mim sem que o seja para todos" (23). O crime é ação valiosa pelo simples fato de ser resultado desta escolha. "Eu não sou culpado!" grita Orestes depois do delito (24). O remorso é mau, pois revela que a opção não foi realmente feita. "O mais vil dos assassinos é aquêle que tem remorso" (25). - O homem é conflito, é tensão face ao

(21) - SARTRE - L'existentialisme est-il un humanisme? - pag. 37 (22) - SPINOZA - Ética, V, proposição XIII, escólio.

(23) - SARTRE - L'existentialisme est-il un humanisme? - pág. 25

(24) - SARTRE - Les Mouches

(25) - idem 
mundo. Nêle brigam a tendência à sociabilidade e a inclinação a isolar-se - a sociabilidade insociável. O outro é causa de limitação, de amesquinhamento: transforma-nos em coisa, em objeto, no "en-soi" - sartreano. O outro é o inferno.

No meio dêste desespêro, desta angústia, dêste niilismo ateísta, restam algumas palavras de esperança, de alegria, no existencialismo cristão, onde o homem é visto como "abertura para o outro", portanto amor (26) e onde o "valor inalienável da pessoa" está "na perspectiva da fraternidade, não na igualdade" (27).

Inspirado no existencialismo de Heidegger, mas sob orientação cristã, o professor de Filosofia do Direito da Universidade do Saarbrücken, Werner MAIHOFER, discípulo e sucessor de Erick WOLF, procura também o retôrno às coisas em si mesmas, o retôrno ao homem concreto. Êle mesmo nos dá a síntese de seu pensamento: "Colocamos a questão do fundamento do Direito na vida do próprio homem, na sua existência concreta no mundo, que se revela como uma dialética da natureza das coisas e da vocaçãa do homem. Reconhecemos como sendo fundamento do Direito a derelicção do homem num mundo inumano e medida do Direito o pro-jeto no sentido da vocacão humana. Segue-se que o Direito não tem seu fundamento em condições históricas passageiras da natureza humana e da estrutura social, que podemos superar um dia, como acreditam aquêles que se fixam no fenecimento do Estado enquanto poder políticc, e do Direito, enquanto coação formal, mas em dados ontológicos pertinentes à existência do homem neste mundo. Assim, o Direito Positivo e o Direitc. Natural nos parecem, no fim de contas, momentos fundados, um como o outro, na histcricidade da existência e ligados, no horizonte do passado e do porvir da situação humana. O Direito Natural, pois, é o transcen der, constantemente exigido, do Direito Positivo, no sentido do direito do homem a uma existência digna do homem e digna de ser vivida" (28).

O título das obras fundamentais de MAIHOFER (Natur der Sachen e Recht und Sein) revelam de logo sua preocupação jusnaturalista. E jus-naturalismo que se pretende concreto, porque parte da "natureza concreta do homem"; opõe-se ao racionalismo jus-naturalista e põe entre parênteses o problema de Deus, por entendê-lo dispensável às cogitações sôbre a natureza do Direito e os critérios de Justiça.

(26) - MARCEL - Journal Métaphysique

(27) - MARCEL - La dignité humaine, págs 167/174.

(28) - MAIHOFER - O Direito Natural como transcendência do Direito Positivo (in APD, 1963, 8, pág. 177).
A humanização do mundo desumano é tarefa que o homem realiza graças à sua temporalidade. A História, pois, não é em si mesma nem determinada nem determinante da conduta humana; ao contrário, é o homem que a faz, na forma como se relaciona com os outros e com o próprio mundo. "O homem não é só o prọduto das circunstâncias e de suas relações, mas também seu produtor; não sòmente a vítima da história mas também seu autor" (29).

E é na humanização do mundo caótico, "da estrutura contraditória, misteriosa e má da própria realidade" (30) que surge o Direito. Direito "é a discórdia (eris), o conflito (polemos) dos contrários, como já vira Heráclito" (31); “o que, em última análise, fundamenta o Direito não é a natureza antagônica do homem, mas a estrutura antagônica, antinômica, paradoxal mesmo, do próprio mundo" (32).

O homem é relação com o outro. Ao contrário do que pensa Heidegger, a autenticidade do homem não está no "ser-êle-mesmo" mas no "ser-como". "A validade (do Direito) surge da autenticidade histórica do próprio ser. Não da historicidade até hoje apontada pela filosofia da existência como verdadeira e própria historicidade, ou seja, a subjetividade do ser-êle-mesmo na autenticidade do seu ser-no-mundo, mas a historicidade totalmente diversa, do mundo do 'eterno retôrno do mesmo' (Nietzsche), do mundo do 'espírito objetivo' (Hegel), em outras palavras, a historicidade da objetividade do ser-ccmo, da autenticidade do ser como pai ou irmão, espôso ou filho, juiz ou médico, não em qualquer tempo e qualquer lugar, mas hoje e aqui" (33).

No relacionamento com o outro, podemos tomá-lo como neutro, sem significação para nós (no máximo com valor instrumental), ou tomá-lo como eqüivalente, como essencial à relacão. A partir desta segunda forma de relacionamento, registra MAIHOFER a existência de pares sociais, de relações inter-humanas necessárias, indissociáveis, as situações existenciais típicas. "A existência social concreta constitui-se pelo que chamamos natureza das coisas no mundo dos homens: pelo ser subjetivo-objetivo do homem no mundo dos homens, como comprador-vendedor, proprietário-locatário, doutor-paciente, juiz-acusado, homem-mulher; são complexos e conexões não sòmente subjetivo-objetivas, mas inter-subjetivas entre homens, que determinam o caráter específico

(29) - MAIHOFER - idem, pág. 189

(30) — idem, pág. 184

(31) - idem

(32) — idem, pág. 186

(33) - MAIHOFER — Die Natur der Sache, p. 171 
e típico de cada situação social, e que não podem ser compreendidas como matéria social, puramente material" (34).

A fim de que os pares sociais típicos sejam o que são, respeitem sua ontologia, segundo um modêlo ideal, faz-se necessária a obediência a princípios, a regras imanentes. E aí vão situar-se as regras jurídicas naturais.

Ocorre que o "homem concreto" não é por natureza, concluído mas, pela disposição de sua liberdade, deve, no jôgo das circunstâncias, constituir-se, acabar-se, desempenhar uma missão histórica. Não é determinação absoluta nem indeterminação total mas a resultante dialética dêstes dois contrários. "O homem, enquanto animal fixo (Nietzsche), não está determinado em sua essência nem por Deus nem pela natureza (enquanto imagem de Deus), mas êle mesmo realiza seu ser, na compreensão e assunção de sua missão. É, em última análise, o produto quer das circunstâncias (e da ordem a ela imanente) nas quais realiza sua essência, quer de sua própria decisão, que êle mesmo deve tomar, que ninguém lhe pode arrebatar e que a ninguém pode transferir. (...) $\mathrm{O}$ homem real, em sua existência no mundo, é essencialmente tanto o produto de suas circunstâncias como de si mesmo. Sua existência concreta no mundo é, em outros têrmos, produto daquilo que the foi dado e daquilo que lhe foi propcsto fazer; resulta de uma dialética entre natureza das coisas e vocação humana" (35).

Desta forma, na concepção de MAIHOFER, Direito Natural, natureza das coisas ou natureza do homem é "êste projeto da determinação histórica do ser do homem nas suas relações com o outor homem" (36). "Direito Natural, concebido como direito existencial, isto é, como direito a uma existência conforme à missão do homem, representa o conceito de uma exigência que se põe diàriamente ao jurista, de adequar cada vez mais as relações humanas a uma imagem diretriz, a um arquétipo de uma ordem digna do homem, concebida como ordem onde reine a maior liberdade e a maior segurança possíveis. Ordem que possibilita uma vida digna de ser vivida no Leste ou no Oeste - embora sob formas totalmente diferentes - , ordem da maior satisfação possível das necessidades humanas e que proporcione o maior desenvolvimento possivel das faculdades." - "Direito Natural é, assim, para nós, o conceito de uma evolução e de uma revolução humanas, constantemente bus-

(34) - MAIHOFER - Direito e Natureza das Coisas na Filosofia Alemã (Colóquio de Filosofia do Direito Comparada), Pars, 1965, pág. 131.

(35) - MAIHOFER - O Direito Natural como transcendência do Direito Positivo, p. 179.

(36) - idem, pág. 187 cada, visando a conformá-las a uma sociedade verdadeiramente humanas" (37).

Põe-se a mesma questão: soluciona o existencialismo jurídico de MAIHOFER a antinomia entre ser e dever ser jurídicos?

Nos propósitos do autor, procura-se apontar como valioso o fato mesmo da existência humana. E nesta identificação entre existência e valor estaria a solução do problema. Nas últimas conseqüências jurídicas, teríamos a identificação entre Direito Natural e Direito Positivo. O Direito deveria ser, por natureza, o que de fato é. Em outras palavras, a negação do jus-naturalismo e mais uma volta ao positivismo jurídico como na dialética hegeliana, onde o escravo deveria ser escravo por ser escravo... esquecido o autor, como acentua o Professor de Strasburgo, DONIUS, que "os escravos se revoltam" (38) e nesta revolta expressam, na existência, a busca de um ideal cujo valor transcende os limites da própria existência.

A permanecer em tal posição, deveria MAIHOFER demonstrar que "o fato (existência humana) é valor e que o valor é fato (existência humana)", como insiste a crítica. Identificação entre fato e valor que só seria possível ao preco de um círculo vicioso: "valorizar primordialmente o fato, o real, como justo, como digno de fundamentar a norma jurídica, para descobrir em seguida, nos mesmos fatos, o valor que lhes fôra antes atribuído" (39). MAIHOFER procura afastar a dificuldade acenando para uma transcendência ao Direito positivo: a "sociedade verdadeiramente humana, digna do homem, digna de ser vivida". Conseqüentemente, o valor sob cuio modêlo deve constituir-se o Direito Positivo não é mais algo real, do homem concreto, mas uma forma ideal de existência "com o máximo de liberdade e o máximo de segurança, o máximo de satisfação das necessidades e o máximo de possibilidade de desenvolvimento das virtualidades humanas".

Chega-se, assim, a um epílogo que mantém íntegro o dualismo kantiano, em que pese o manifesto propósito de superá-lo; resta ainda uma ruptura abissal porque, pretendendo ter superado a dificuldade pela extinção de um dos têrmos do binômio (o mundo ideal), joga implicitamente com êle.

(37) - MAIHOFER - Direito Natural como transcendência do Direito Positivo, p. 179

(38) - Charles DONIUS - Existentialisme, phénoménologie e phi losophie du droit - APD, 1957, pág. 230

(39) - Nicos POULANTZAS - Notes sur la phénoménologie et l'existentialisme juridiques - APD, 1963, pág. 229 . 


\section{O marxismo jurídico}

Também o marxismo pretende ser superação dêste dualismo pelo retôrno ao concreto; e, como no existencialismo, o que de concreto pretende salvar é o próprio homem. Mas aqui o homem terá como dimensão fundamental sua sociabilidade e historicidade, o que, afinal, irá reduzi-lo a um gênero (perdido o valor pessoal), a uma radicação partidária.

Neste contexto, é de logo recusado o Direito, como reminiscência da ideologia burguêsa, capaz de fazer esquecer o homem real, de aliená-lo. A permanência do Direito na sociedade socialista é transitória, concessão temporária, imposta pelas circunstâncias da revolução. "No atual período de transição, o proletário deve utilizar necessàriamente, em seu interêsse de classe, essas formas (Moral, Direito, Estado) herdadas da sociedade burguêsa" (40), afirmava PASHUKANIS, identificando o direito socialista ao direito burguês, o que lhe valeu mais tarde violenta contestação de VYSHINSKY (41).

Este Direito, transitório, "construído sôbre a estrutura econômica" (42), reduz-se, em última análise, à fôrça - é uma técnica de conquista e manutenção no poder: é a vontade do econômicamente poderoso (aquêle que detém a propriedade cos meios de produção) imposta coercitivamente aos demais, a fim de impedirlhes a ascenção econômica e política. E o agravo de MARX, no Manifesto Comunista, ao "direito burguês": "Vossas idéias são produtos do sistema burguês da produção e de propriedade, assim como vosso direito não é senão a vontade de vossa classe erigida em lei; não há nesta vontade nada além das necessidades materiais de vossa classe. - É por interêsse que erigís em leis eternas da natureza e da razão vossas relações de produção e de propriedade, que rão têm senão um caráter histórico e que o próprio processo de produção fará desaparecer" (43). Mas a mesma característica opressora não é negada nem ao Direito socialista, na fase de transição, rumo à sociedade comunista. $\mathrm{O}$ mestre do Direito soviético, representante da linha sociologística do pensamento jurídico, "STOUTCHKA, Comissário do Povo para a Justiça em 1918, em obra publicada em 1921, refletindo exatamente o ponto de vis-

(40) - PASHUKANIS - Teoria Geral do Direito e do Marxismo, apud KELSEN, Teoria Comunista do Direito e do Estado, tr., BA, 1858, pág. 153

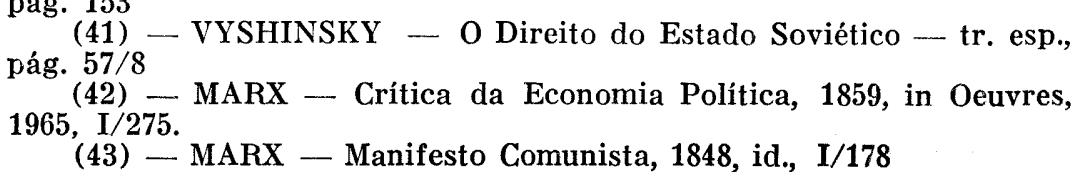

ta marxista, definia o direito como sistema de relações sociais correspondente aos interêsses da classe dominante, cujo funcionamento é garantido pela fôrça organizada, portanto material, desta mes ma classe" (44). E é a lição repetida por um sem número de juristas em obras oficiais recentes: ROMASSHKIN, KOTOK, CO LUNSKII, STROGOVICH e CSABA VARGA (45). A única distinção entre o ordenamento jurídico burguês e o soviético estaria na consciência clara, neste último, de sua condição opressora e na revelação desta condição.

De forma violenta, determinante até do expurgo de juristas como STOUTCHKA e PASHUKANIS (inclusive o desaparecimento dêste último), formou-se um grupo de intérpretes do Direito marxista, na fase socialista, liderados por VYSHINSKY, procurando negar ao ordenamento jurídico socialista o caráter opressor. Consistiu a argumentação em afirmar que a opressão, nesta fase, é obra de todo o povo e, sendo todos opressores, não há oprimidos. Artifício sofístico, inveraz, fundado na identificação da vontade de todos com a vontade da classe trabalhadora. "Nossas leis, diz VY. SHINSKY, expressam a vontade de nosso pova, o qual governa e está criando uma nova história, sob a direção da classe trabalhacóra. Entre nós, a vontade da classe trabalhadora se ccnfunde com a vontade de todo o povo. Isto dá fundamentos para falar mos em nosso direito socialista soviético como expressão da vontade de todo o povo" (46).

Pôsto à margem o pensamento de VYSHINSKY, manifestamente deformador do real, o direito soviético se auto-revela como opressão de classe. "Esste Direito é, ao menos em seu conteúdo, desigual como todo Direito" (47). Nenhuma forma de ordena mento jurídico escapa à acusação de essencialmente opressivo. "Todo Direito pressupõe desigualdade. Todo Direito consiste na aplicação de uma regra única a pessoas diferentes, a pessoas que, na realidade, não são nem idênticas nem iguais. Assim, o 'Direito igual' equivale a uma violação da igualdade, a uma injustiça" (48) - $\mathrm{O}$ jugo opressivo, característica fundamental do jurídico, apare-

(44) - STOYANOVITCH - La Philosophie du Droit en URSS, Pa ris, 1965, pág. 43

(45) - Fundamentos del Derecho Sovietico - Moscou, 1962, pág 19/20, 42/43; Csaba VARGA - A Definição do Direito na Teoria Socialista do Direito (APD, XII/187); Alguns Problemas da Definição do Direito na Teoria Socialista do Direito (APD, XII/199) pág. 184

(46) - apud KELSEN, op. cit., pág. 185 e STOYANOVITCH, op. cit.

(47) - MARX - Carta a Bracke, 1890, apud STOYANOVITCH, Le Régime Socialiste Yougoslave, Paris, 1961, pág. 103

(48) - IENINE - O Estado e a Revolução, tr., Rio, 1961, pág. 113 
ce, assim, como conseqüência das desigualdades sociais, expressas pela pluralidade de classes econômicas. E, expressão da desigualdade, o Direito é sempre injustiça.

Vai a tal ponto a antinomia Direito-Justiça no sistema, que estas duas realidades, em sua dinâmica, são concebidas como movidas em razão inversa: quanto mais se fortalece o Direito, mais se tende à injustiça; quanto mais se busca a realização da Justiça, mais se esvai o Direito. De tal forma que, "no dia em que pudesse existir, hipotèticamente, um Direito igual e, portanto, conforme a uma idéia absoluta de Justiça, neste mesmo dia êle já não existiria mais ... Direito e igualdade, Direito e Justiça, não podem jamais coincidir" (49)

Mas os esquemas do materialismo dialético e do materialismo histórico têm por norte uma sociedade ideal, sem classes, onde reine a abundância dos bens econômicos e, por isso mesmo, não haja necessidade de ninguém oprimir a ninguém. Paraiso terreno a que se tenderia na medida em que fôssem se extinguindo as classes sociais, as quais arrastariam consigo simultâneamente para $o$ fenecimento Estado e Direito. O Direito é, pois, fenômeno transitório, peculiar à época da ditadura do proletário, oriundo do período burguês e tendente ao total desaparecimento. "O fenecimento das categorias — não dos mandamentos — do direito burguês não significa, de forma alguma, que elas sejam substituídas por novas categorias de direito proletário .... O fenecimento das categorias do direito burguês significa, em tais condições, o fenecimento do direito em geral, quer dizer, o desaparecimento gradativo do elemento jurídico nas relações humanas" (50).

Virá, pois, o desaparecimento do Direito juntamente com o desaparecimento das classes. Ou seja, a classe proletária, absolutizando-se no poder, providenciará na extinção definitiva de tôdas as demais e, ficando só, terá feito desaparecer as desigualdades decorrentes da pluralidade de classes. Não haverá, então, necessidade de manter instrumentos de opressão, entre os quais se inscreve o Direito. "Com a realização da sociedade comunista e a manutenção voluntária das regras fundamentais da convivência humana, não haverá mais necessidade de molestar os Tribunais de Justiça, Polícia, julgamentos e cárceres, advogados e Promotores, Brigadas de investigação e verdugos, e os demais agentes profissionais da administração da justiça ... Em conseqüência à liquidação da propriedade privada, também as normas de Direito Civil serão su-

(49) - STOYANOVITCH - Marxisme et Droit, Paris, 1964, pág. 153. (50) - PASHUKANIS, id., pág. 153 pérfluas. A mesma sorte terão também, uns após os outros, os diversos direitos estatais e intituições do Estado" (51).

A fase política atual, no Estado Soviético, corresponderia ao período de transição, no qual faz-se ainda necessária a afirmação do Estado e do Direito, como processo necessário à liqüidação das classes sociais. "Nós somos pelo fenecimento do Estado e, ao mesmo tempo, nós somos pelo fortalecimento da ditadura do proletariado, que representa a mais potente autoridade de tôdas as formas de Estado que existiram até hoje. Desenvolver ao máximo o poder do Estado, visando a realizar as condições sob as quais êle poderá desaparecer: eis a fórmula marxista. É uma contradição, dir-se-á? Sim, há aí uma contradição. Mas esta contradição é a própria vida e reflete completamente a dialética marxista" (52). Mantém-se, pois, o Direito, mas em vias de desaparecimento, processo que "será extremamente lento" (53).

$\mathrm{Na}$ linguagem de STRUMILIN, portanto, alcançada a sociedade comunista, ideal, dar-se-á apenas a "manutenção voluntária das regras fundamentais da convivência humana". Que se deve entender, pois, quando o marxismo fala em desaparecimento do Direito? A resposta não é difícil. O que tende à morte são regras de Direito Positivo relativas à propriedade e às relacõos humanas decorrentes de uma determinada forma de relação de produção (54); desapareceria, também, a "coação estata!", substituída por uma obediência a regras num "crescente caráter voluntário" (55). Mas que regras fundamentais de convivência humana são estas que permanecem? A resposta está em MARX: "Devese considerar o legislador como um sábio que prescruta a natureza. Êle não faz as leis, êle não as inventa, êle não faz senão fórmulas, êle enuncia, sob forma de leis positivas conscientes, as leis internas das relacões espirituais" (56). Este Direito permanecerá: "Libertado da escravidão capitalista, dos indiscritíveis horrores da selvageria, dos absurdos e infâmias da exploração capitalista, o povo se acostumará gradualmente a observar as regras elementares da vida social, conhecidos a séculos e repetidas a milê-

(51) - STRUMILIN, 1960, apud WETTER-IEONHARD, A IdeoloSoviética, 1962 tr., Barcelona, 1964, pág. 608/9. (52) - STALIN - 18\% Congr. do PC na URSS,

Le Regime Socialiste Yougoslave, pág. 107/8 NETTER.LEONHARD, id., p. 586

(54) - STOYANOVITCH - Marxisme et Droit, págs. 87, 95 e 154

(55) - Csaba VARGA, Alguns Problemas ... pág. 199

(56) - MARX - in Rheinische Zeitung, 1842, apud Hasso JAEGER, Savigny et Marx, APD, XII, 19, pág. 77 
nios nos textos escolares; se acostumará a observá-las sem coação, sem compulsão, sem subordinação, sem o aparato compulsivo especial que se chama Estado" (57).

Eis como um sistema jurídico que, em nossa época, se revela aparentemente como a mais terrível forma de positivismo jurídico, por ser a consciente utilização do Direito como fôrça pura, como instrumento de opressão, é essencialmente estruturado sôbre o pressuposto da existência e da validade do jus-naturalismo. Rigorosamente falando, o sistema jurídico marxista não se baseia no fornecimento mas no fortalecimento do Direito. Enquanto Direito Positivo, é mais forte, na fase da ditadura do proletariado, como instrumento de extinção das classes sociais; e ainda mais poderoso na sociedade comunista, quando se imporia diretamente às consciên. cias, naquilo que tem de essencial.

Mas o homem concreto está novamente perdido. Se, nos seus fundamentos emocionais, pretende o marxismo participar da luta contra a fome, contra a exploração do homem pelo homem; se, a julgar pelas reivindicações sociais de que está prenhe, move-se em razão de um sentimento de injustiça face aos oprimiços; se, sublimando ao máximo, dentro de seus limites materialistas, visa à redenção do homem pelo próprio homem; em suas conclusões o homem, como realidade concreta, individual, nada vale. Importa apenas a dimensão social. "O indivíduo é ser social". "Ainda que seja um indivíduo particular - e é justamente sua particularidade que faz dêle um indivíduo e um ser social realmente individual o homem é, entretanto, a totalidade, a totalidade em idéias, a existência subjetiva da sociedade, pensada e sentida em si." (58). Por isso o "pessoal" não conta no homem e a sociedade (concretamente falando, o Estado, o Partido ou Chefe Político) o liquidam com reverente piedade, em nome do próprio sistema. Só é válido o so. cial.

E isso porque o homem é concebido como um ser sem origem nem destino - sem Deus. "Odeio todos os deuses!" é o brado de MARX, bisando Prometeus, em sua tese de doutorado. "O comunismo começa imediatamente pelo ateísmo, mas o ateísmo está ainda muito longe de ser o comunismo, porque o ateísmo não é senão o feito de uma abstraç̃o" (59). Afastada a teoria criacionista, porque afastada a explicação teísta, explica-se o homem por "geração espontânea" no contexto da matéria; sua destinação é a morte, "dura vitória da espécie sôbre o indivíduo." (60).

(57) — LENINE, Est. e Revolução, pág.

(58) - MARX - Manuscritos de 1844, pág. 117

59) - MARX - Manuscritos de 1844, pág. 115

(60) - id., pág. 117
É preciso que se ponha, finalmente, a mesma pergunta anterior: resolve-se, no marxismo, o dualismo realidade-idéia? $\mathrm{E}$ a resposta é necessàriamente negativa. Mantêm-se separados o fenô$m^{e_{n o}}$ jurídico, expresso na transitoriedade do Direito Positivo, e a realidade essencial do Direito, revelada na permanência de "regras sociais de conduta" na sociedade utópica. A preocupação pela concreticidade gera, no marxismo jurídico, conclusão assemelhada à da visão existencialista: a afirmação de um transcendente contraditòriamente imanente à matéria. No existencialismo, o transcendente é aquilo que o homem cria por sua liberdade, no existir; no marxismo, o Direito que transcende o plano positivo, é o Direito, visionado numa fase utópica que pretende histórica. $\mathrm{O}$ essencial do $\mathrm{Di}$ reito não está num mundo platônico de idéias mas num momento determinado (ou indeterminado) da história. Em que pese o recurso paradoxal a um "transcendente imanente", mantêm-se o dualismo básico.

\section{LOGÍSTICA E DIREITO}

Se a preocupação era superar a antinomia fato-idéia, se a superação $\epsilon$ ra buscada a partir da eliminação de um dos têrmos conflitantes, era lògicamente possível a identificação do direito com a idéia em si mesma. Admitindo-se, mais, com a Fenomenologia, a redução da realidade à idéia, não há porque, a partir daí, preocupar-se com a realidade. A ciência humana deve, então, restringirse ao "Eidos" e seus relacionamentos. Tal como ocorre na mate-

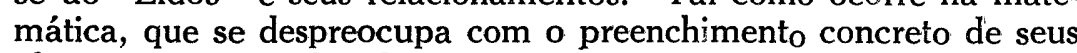
objetos para considerá-los tão sòmente na dimensão etérea em que os cria. Aproximação, aliás, tão viva, que chegou a estabelecer como problema a redução da Lógica à Matemática ou da Matemática à Lógica. (61)

Poderíamos surpreender em KELSEN, a figura jurídica exponencial de nosso século, o tratamento do Direito como mero "Logos", pois mais que uma "teoria pura do Direito", realiza êle uma "teoria do Direito puro", sem conteúdo concreto, histórico.

A preciosidade porém do pensamento lógico jurídico está na revivescência da lógica aristotélica. (62) Seis livros compõem o "organon": as Categorias, o Tratado da Interpretação, os dois A-

(61) - Kalinowski, Introduction à la Logique Juridique, pág. 2) (62) - Vide, a propósito, o estudo de PERELMAN, «Justice et Raison», Bruxelas, 1963, pág. 99 e 581 ). 
nalíticos, a Tópica e a Refutação aos Argumentos Sofísticos. Nêles, dois métodos são estudados para busca da verdade: a análise (Analítica) das leis internas que presidem ao relacionamento das idéias, à formação dos juízos e raciocínios e o diálogo (Dialética), voltado à persuação, à obtenção da convicção do interlocutor. A persuação pode ser atingida ou porque os interlocutores encontrem pontos de vista comuns, que dispensam demonstração ("Topoi"), a partir dos quais podem conferir a validade dos demais momentos do diálogo, ou porque um dos interlocutores, graças a fatôres extrínsecos, consiga obter a aceitação do auditório (Retórica).

A Tópica, retomada em nossos dias de forma exemplar por Viehweg (63), tem como objeto o fato de que todo o conhecimento humano se funda em pontos de partida indemonstráveis ("Topoi", lugares comuns ou esquemas argumentativos). Somos incapazes de demonstrar "ad infinitum". No processo de regressão demonstrativa, paramos em teses para nós suficientemente evidentes ou remontamos à evidência dos primeiros princípios. Pois bem, descobrir e estabelecer os "Topoi" do diálogo, testar-lhes a validade ou a validade das afirmações dêle deduzidas, é, em especial, normal na atividade profissional e na ciência jurídica. A análise científica do Direito parte de "Topoi" mais ou menos indiscutíveis, axiomáticos, como a lei, os costumes e a jurisprudência. Por isso, a Tópica aristotélica renasce para o jurista moderno. Por outro lado o debate processual é uma argumentação (mais que uma demonstração) visando a convencer o julgador. Neste mister, poderá ter mais êxito aquêle que, objetivamente menos acertado, disponha de elementos extrínsecos mais convincentes (qualidades morais de quem expõe, sentimentos comuns com os do magistrado forma estilística da exposição) : é a Retórica, arte de persuadir, que retoma posicão de destaque no estudo jurídico.

Indiscutivel a estrutura lógico-matemática do método jurídico, que permitiu a Savigny elogiar os jurisconsultos romanos dizendo que "o trabalho dêles adquire segurança que não se encontra fora da matemática, a ponto de poder-se dizer sem exagerar que êles calculam com seus conceitos" (64). Mais que isso, indiscutível a estrutura lógico-matemática do próprio Direito. Para ficar na mesma fonte ilustrativa: "em todos os triângulos dão-se certos elementos de cuja conexão decorrem necessàriamente todos os de mais. Da mesma forma, tôdas as partes de nosso Direito possuem alguns pontos a partir dos quais todos os outros são dados: podemos chamá-los postulados fundamentais. Descobri-los e, partindo

(63) - Viehweg - Theodor - Topik und Jurisprudenz, Muencsen,

(64) - in Bobbio N., Diritto e Lógica, Rifd, 1962, pg. 18 dêles, reconhecer a conexão interna e o tipo de afinidade de todos os conceitos e normas jurídicas, é uma das mais difíceis tarefas de nossa ciência e é exatamente aquilo que dá ao nossos trabalho caráter científico." (65). Usando um exemplo mais concreto: como, na Alemanha, "o recurso de revisão só possa fundamentar-se na violação do Direito, pela sentença, a Côrte Suprema Federal entendeu necessário considerar as leis da lógica como normas de Direito não escrito." (66) E porque há uma lógica intrínseca no Direito, cumpre ao jurista não descurar o estudo desta lógica, não permanecer no exame das provas denominadas por Aristóteles analíticas mas propor-se também a questão das provas dialéticas.

A Escola Belga de PERELMAN volta-se à Lógica Jurídica em têrmos aristotélicos. Não fica indene o direito, porém, à tentação moderna de constituir um ramo de Lógica válido apenas para o mundo dos valores (Lógica Deôntica). Além disso, orientase o pensamento lógico no sentidio de constituir uma linguagem simbólica, substituindo conceitos e palavras, juízos e proposições, por letras, números ou símbolos gráficos especiais. É a Semiótica, proposta por MORRIS em 1932, subdividida no exame do relacionamento dos símbolos (Sintática), o significado do relacionamento dos símbolos (Semântica) e a aplicação aos objetivos humanos (Pragmática).

Inegável, pois, o conteúdo lógico da realidade jurídica; inegável, porém, a irredutibilidade do Direito à sua dimensão lógica. Esta consciência de limites não têm tido, porém, os lógicos-jurídicos, a ponto de levarem a prelo obras redigidas apenas através de símbolos incompreensíveis ou acessíveis a um pequenissimo número de iniciados. "Estamos impressionados com a especialização abstrusa em que se transformou a lógica moderna, com suas páginas inteiramente cheias de equações exotéricas e símbolos incompreensiveis" (67).

De resto, se é válida a matematização parcial do método jurídico, é totalmente recusável a idéia de reduzir o Direito a fórmulas matemáticas; e isso pela simples razão de que o Direito, ao contrário da matemática, tem por objeto a ação humana, o fato.

As observações críticas que percorrem êste trabalho desde o início têm seqüência a partir de afirmação do próprio Kalinowski:

“a Lógica, atingido o estágio da formalização, transformou-se em

(65) - SAVIGNY, «Apud» BOBBIO, Diritto e Lógica, RIFD, 1962, pg. 18)

(66) - KLUG, UIrich - Problemas de Filosofia do Direito, trad. Buenos Aires, 1961, pg. 79.

(67) - VILLEY, M., Donées historiques, APD, 1966, XI, p. VII) 
jeto de ciência. $\mathrm{O}$ binômio real-ideal, no plano jurídico, foi destruído pela proclamação do ideal como única realidade. Retôrno a realidade ela mesmo." (68). Isto é, perdeu-se o Direito como obPlatão, como acertadamente advertia PERELMAN: "Por que razão todos êstes lógicos, que identificam a lógica com uma linguagem formalizada, terminam por conceber estas entidades extra-lingüísticas? ... Trata-se de um mundo eterno de idéias platônicas?" (69).

\section{Cibernética e Direito}

Reduzido, afinal, o Direito à sua dimensão puramente lógica (a idéia), traduzida a idéia no símbolo que lhe corresponde, combinados os símbolos numa linguagem (simbólica), chega-se ao ponto em que pensar o Direito e editar, interpretar ou aplicar a lei passam a ser meros processos de combinação lógica de símbolos. Combinação, de resto, mais adequada a um aparelho programado (o computador eletrônico) que à inteligência humana. A cibernética é, assim, o "traço de união entre a Lógica Simbólica e a Física" (70).

A racionalizacão pura do Direito, a matematização absoluta de seus dados conduziu, assim, paradoxalmente, à máxima concreticidade do Direito - a substituição do Jurista e do Legislador por máquinas encarregadas das tarefas que desempenhavam.

É certo que a matematização das normas jurídicas pode conduzir a grandes benefícios enquanto, pela automatização, proporciona a memorização e a combinação de dados para a técnica jurídica. Será, no futuro, sem dúvida, importante, para o Juíz, o contrôle do texto vigente sôbre a matéria "sub judice", ou o exame dos antecedentes jurisprudenciais do caso, feitos pela máquina. Também ao legislador importará saber como se insere seu projeto no ordenamento jurídico positivo. Ao profissional da advocacia finalmente, os dados controlados pela máquina facilitarão o trabalho, permitindo resultados mais rápidos e mais seguros. Neste particular, a estranha história do Direito, que o levou ao máximo de abstração para fazê-lo tombar no máximo de materialização, revela-se como uma história positiva, em benefício para o homem.

" $\mathrm{Na}$ medida em que os problemas do direito são racionais, a última e mais moderna conseqüência de uma construção exata de

(68) - KALINOWSKI, G., Introduction a 1 a Loguqie Juridique, pag. 33

(69) - PERELMAN, Ch., Justice et Raison, pág. 191

(70) - KALINOWSKKI, Introduction a la Logique Juridique, pg. 180). sistemas teóricos e empíricos do direito é a matematização das ncrmas. A cibernética e a automatização se transformam, por conseguinte, em problemas atuais, tanto da teoria como da praxis do direitc. A automatização eletrônica foi introduzida em alguns países, p.ex. na Alemanha, para aplicação do direito impositivo e de seguros; aqui a praxis precede à teoria. Deve-se ter em conta que os casos práticos mencionados não se referem sòmente ao manêjo de questóes que podem ser solucionados numèricamente. Demonstra-o o fato de ter sido necessário incluir normas jurídicas no programa das máquinas.

O fato de que a cibernética e a automatizacão interessam só a uma parte do trabalho dos juristas não é nenhum contra-argumento, pois pode-se considerar vantagem substancial o fato de, mediante a matematização, a cibernética e a automatização, tornarse possível indicar com mais exatidão os limites entre os métodos de trabalho racionais e irracionais do jurista." (71)

Mas o pensamento jurídico moderno não se satisfaz vendo no computacior apenas um instrumento auxiliar da técnica jurídica; quer vê-lo também como máquina de pensar o Direito, de fazer ciência jurídica.

Preocupado inicialmente com a Lógica Jurídica, o Professor de Fil. do Direito da Universidade de Colônia, ULRICH KLUG projeta um computador, programado de acôrdo com os esquemas da lógica analítica de Aristóteles, reduzida a símbolos matematizados (72). A cada espécie possível de silogismo, corresponderia especial forma de circuito. Obtido, isso, pretende propor premissas (leis, sentenças, aforismos, proposiçôes jurídicas em geral) ao aparêlho e dêle obter resultados lógicos, segundo os princípios aristotélicos do silogismo. A conclusão recolhida não tocaria, pois, à validade da regra, sentença ou proposição, sua adequação às leis de pensar. Nisto consistiria a ciência jurídica programada. E nisto estaria o traço de união entre a Lógíca e a Física modernas, com vistas a facilitar a existência do homem.

E a mais violenta tentativa de reunificação do ideal ao real, na história do Direito. E terrivel tentativa, pois que feita não pelo Homem mas pela máquina. Processo dramático para superar a ruptura Kantiana, conduzindo à desumanização do pensamento, ou melhor, à negação do poder criador do pensar humano. Fundamentalmente. não foi superado o impasse; uma vez mais destruiu-se hipotèticamente um dos termos conflitantes - o pensar.

(71) - KLUG, Ulrich. Problemas de Fil. do Dir., trad. Buenos Aires, 1961, pg. 28/9

(72) - KLUG, Ulrich - Lógica Jurídica trad. Caracas 1961. 


\section{Filosofia Perene e Direito}

$\mathrm{Na}$ paisagem do pensamento jurídico atual, perdeu-se a compreensão do Direito como algo pertinente à natureza, algo objetivamente dado ao pensar. Se concebido como algo pensado, tratase de idéia que nada tem a ver com o real; se concebido como realidade, é apenas algo que se impõe pela fôrça e não conquistado, descoberto pela razão. Ruptura completa entre o pensar e o ser do Direito.

É notável que, apesar desta dominância, registre-se, como significativa para o Direito e sua história, uma linha de pensamento que nasce na Grécia antiga, sofre as vicissitudes normais do tempo, mas dura ainda hoje, produzindo os melhores frutos para o conhecimento humano em geral, para o conhecimento jurídico em particular. E exatamente porque assim duradoura, costumou-se chamála "filosofia perene".

A Filosofia do Direito recebe já os efeitos positivos desta forma de pensar quando, por exemplo, nas primeiras páginas da história-grega, HERÁCLITO fala num Deus capaz de punir o Sol, se êste infringir a rota que lhe foi traçada; ou quando SóFOCLES, pela bôca de Antígone, protesta ante Creon contra um Decreto contrário às leis que os deuses lhe inscreveram no coração. Esta visão da normatividade jurídica como um dado natural impôsto ao legislador positivo e ao pensador do Direito é recolhida, explorada e divulgada pela tríade miraculosa da filosofia grega: em SÓCRA$T E S$, é a preocupacão pelo Bem e sua radicacão ontológica; em PLA. $T \tilde{A} O$ é a busca da natureza do próprio Bem; em ARISTOTELES, a experiência exaustiva da presença do Justo na natureza das coisas e a exploração do processo como a inteligência daí o extrai (abstrai) para desvelar sua idéia. Este rumo do pensamento jusnaturalista é mantido pelos estóicos, vai à Roma especialmente através de CíCERO, inspira as Institutas de Justiniano, é recolhido mais tarde por gênios como AGOSTINHO e SUAREZ e encontra seu esplendor em TOMÁS DE AQUINO.

Tôdas as idéias filosófico-jurídicas atravessaram suas naturais crises, mas esta forma de pensar, ainda quando oculta em mosteiros, floresceu sempre e ressurgiu mais exuberante cada vez que foi dada por morta. Tal resistência histórica testemunha não se tratar de uma teoria estanque, antiquada, que não suporte aperfeiçoamento, mas de uma direção de análise perfectível, suscetivel de renovação.

$\mathrm{Na}$ idade moderna e contemporânea, podemos lembrar as figuras de BLONDEL, BERGSON e MARITAIN ou CATHREIN que, sem serem pròpriamente filósofos do Direito, por suas análi- ses no campo da filosofia prática proporcionaram a revitalização do pensamento jurídico abalado pelo positivismo e o criticismo.

Pela qualidade e repercussão das obras publicadas, porém, o nome que merece ser destacado hoje como representante da Filosofia do Direito de inspiração jus-naturalista-tomista, é MICHEL VILLEY, professor da Faculdade de Direito e Ciências Econômicas de Paris (73). Na comunicação, que apresentou ao Congresso Mundial de Filosofia do Direito, reunido em Gardone Riviera em Setembro de 1967, repudia êle a ruptura da idade moderna entre "Sein" e "Sollen", enquanto cisão da realidade, embora a admita hipotèticamente como processo de análise; mostra como, a partir dêste duo, surgem, de um lado, o idealismo e, de outro, o positivismo jurídicos (incluindo no primeiro Kant e Kelsen e, no segundo, marxismo e existencialismo) (74).

"O ser não se opõe ao dever, como o "Sein" de Kelsen ao "Sollen". Existe o dever-ser. Será necessário retornar a êste truísmo?" (75) E o Direito se situa exatamente neste plano em que o dever emerge do ser. "O homem não é criador das normas, ao menos das normas de direito natural; seu papel não é senão descobri-las, recolhê-las, abstraílas das coisas onde elas são dadas. Quem é seu autor? A natureza, quer dizer, sem dúvida, um Deus, ordenador da natureza; não um Deus confessional, revelado ccmo objeto de crença, mas o Deus dos filósofcs, ao qual qualquer um pode chegar apreciando a natureza." (76) Como o Direito não é apenas Direito natural, como há uma dimensão positiva do ordenamento jurídico, é preciso também explicá-la. Principalmente porque a lei positiva e o aresto parecem ser criação do homem, e não descoberta sua na natureza. Sustenta, então, o Prof. VILLEY, com tôda a tradição tomista, que, "se a lei positiva não exprime o justo, não merece êste nome: "uma lei injusta não é uma lei; um instrumento não é um instrumento se não cumpre efetivamente a função correspondente à sua essência". (77)

(73) - VILLEY, Michel - artigos nos «Archives de Philosophie du Droit», desde 1959

VILLEY, Michel - Leçons d'histoire de la philosophie du droit», $\mathrm{Pa}$ ris, 1957, 1962;

VILLEY. Michel - «La formation de la pensée juridique moderne» Cursos, de 1962 a 1967), Paris, 1968;

VILLEY, Michel - «Consideraciones en pro del Derecho Natural Clasico», Cordoba, 1966 1969

(74) - VILLEY - «Seize Essais», pg. 86

(75) - VILLEY, Seize Essais, pg. 88

(76) - idem, pg. 66
(77) - idem, pg 90. 
No Brasil, há mais de três décadas o Prof. Armando CÂMARA, na Faculdade de Direito de Pôrto Alegre, fiel à orientação tomista de retomada do jus-naturalismo clássico grego para aperfeicoá-lo, no processo socrático de seu magistério, vê o Direito como "técnica de realização do valor Justiça na história", valor que, na peculiaridade de seu pensamento, não deve ser entendido à romana (como até VILLEY o faz), o "suum cuique tribuere", nem como virtude, tal como se encontra mesmo em Sto. TOMÁS, mas que possui fundamento ontológico. Na estrutura de seu pensamento, destaca-se a posição teísta, afirmando a apreensão racional da existência de um Deus criador e ordenador do universo; conseqüentemente, a afirmação da ordem ontológica, revelada pela presença de fins no ser; na superação das dificuldades gnosiológicas ,a aceitação das soluções do dogmatismo moderado, o intelectualism 0 e o realismo crítico; em antropologia, a racionalidade do homem como fundante de sua liberdade e sua sociabilidade; no que se refere às questões axiológicas, onde mais se revela a originalidade de seu pensamento, a fundamentação do valor no ser (categorias que não se opõem nem confundem mas se distinguem), definindo valor como "o próprio ser visionado racionalmente numa perspectiva teleológica" ou, numa outra forma definidora, como "a conformidade do dinamismo do ser com seus fins"; com estas linhas mestras, chega à sua visã $\supset$ da axiologia jurídica, onde define Justiça como "a conformidade de uma relação inter-pessoal com os fins da vida enquanto a vida é convívio (ou bem comum)", concebendo ainda bem comum como "o conjunto das condições pessoais e sociais de vida que asseguram a realizacão dos fins humanos."

Não nos cabe a exposição de uma forma de pensar que se quer oral e nesta oralidade tem produzido seus invejáveis frutos. Naquilo que importa, porém, a êste trabalho, trata-se de ótimo exemplo da fecundidade do jus-naturalismo clássico, agora genialmente tocado pelas conquistas da axiologia. Não há, aqui, ruplura entre ser e pensar, ser e dever-ser, Direito e idéia de direito. Há distinção e relacionamento. Direito é um fato valioso que a razão descobre na natureza racional, livre e social do homem e busca, na ordem positiva, inserir no convivio.

\section{TEORIA DOS PRESSUPOSTOS PROCESSUAIS : ENSAIO CRÍTICO}

PROF. WALTER EDUARDO BAETHGEN (*)

1. A nocão dos pressupostos processuais surgiu com o famoso escrito de BUULOW, Die Lehre von den Prozesseinreden und die Prozessvoraussetzungen, Giessen, 1868. (1)

O sentido da teoria de Bülow foi a de substituir a idéia das exceções processuais - defesas opostas à pretensão no que diz res. peito a imperfeiçóes do próprio processo - pela teoria dos pressupostos processuais (Prozessvoraussetzungen), que constituem verdadeiras condições prévias para a existência (ou a formação) da relação processual.

No processo romano da época clássica, dividido o processo em duas fases, muitos dos hoje chamados pressupostos processuais eram resolvidos "in iure", portanto, antes da vinculação do réu ao processo, pela "litiscontestatio".

A teoria romana é inaplicável ao processo atual, pela diversidade de estrutura com que se apresentava o processo formulário, no qual era óecisiva a fase "in iure", a única que se desenvolvia perante a autoridade estatal (pretor) na qual, não obstante, mais se tratavam as questões de processo. (2)

Tendo definido o processo como uma relação jurídica, entendeu BÛLOW que, assim como acontece com as demais relações ju-

* Professor de Direito Judiciário Civil

(1) GOLDSCHMIDT, no seu não menos famoso, Der Prozess als Rechtslage, Berlin, 1925, inicia a parte crítica de sua obra com a referência à monografia de Bülow, considerando-a como marco fundamental na construção da moderna ciência do processo.

(2) BÜLOW, Die Lehre von den Prozesseinreden und die Prozessvoraussetzungen, Giessen 1868, pag. 290/292 